ASLI QoL 2017
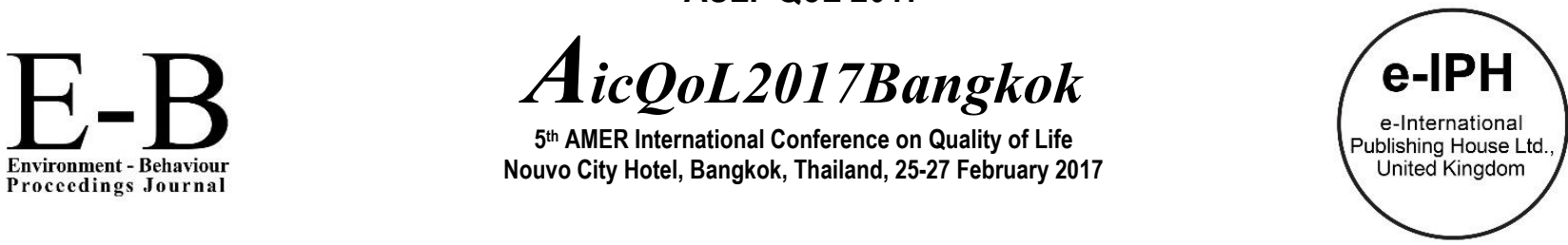

\title{
Product Design Enhancing Environmental Perception and Encouraging Behavioural Change towards Sustainability
}

\author{
Chanon Tunprawat ${ }^{1 \text { *, }}$ Yanin Rugwongwan2 ${ }^{2}$, Wichitra Singhirunnusorn ${ }^{3}$ \\ ${ }^{1}$ Arch D. Student, Faculty of Architecture, King Mongkut's Institute of Technology Ladkrabang (KMITL), 10520, Thailand \\ ${ }^{2}$ Asst. Prof. Ph.D. program in school of Interior Architecture, Faculty of Architecture, King Mongkut's Institute of Technology Ladkrabang (KMITL), 10520, Thailand \\ ${ }^{3}$ Ph.D., Lecturer, Faculty of Environment and Resource Studies, Mahasarakham University (MSU), 44150, Thailand.
}

\begin{abstract}
This study focuses on reducing environmental impact by design and aim to inform the environmental information through product design to support user behavioural change. The objects are to analyse user attribute factors that affect to perception distinction of environmental information, consider environmental data contents and information designs that Influence to user behaviour and evaluating design principles. This research is an empirical research in the methodology used mixed methods. The results will expand the knowledge and theory of sustainable product design to emphasise on user behaviour change theory and the guidelines for daily life product design
\end{abstract}

Keywords: Product Design, Environmental Perception, Behavioral Change, Sustainability

ISSN: 2398-4287@ 2017. The Authors. Published for AMER ABRA by e-International Publishing House, Ltd., UK. This is an open access article under the CC BYNC-ND license (http://creativecommons.org/licenses/by-nc-nd/4.0/). Peer-review under responsibility of AMER (Association of Malaysian Environment-Behaviour Researchers) ABRA (Association of Behavioural Researchers on Asians) and CE-Bs (Centre for Environment-Behaviour Studies), Faculty of Architecture, Planning \& Surveying, Universiti Teknologi MARA, Malaysia.

\subsection{Introduction}

An environmental crisis is a dangerous situation problem (Yusof, Z.B.BT. \& Jamaludin, M., 2015) that affects to all human and creatures on earth. In the present sustainable development concept (United Nations, 1987) brings in the concept of social and economic development by giving priority to environmental impact solving. This concept has been developing from plenty researchers in multiple fields including a science of design. The design for sustainability is an important mechanism that solved environmental problems in a field of product design such as Eco-Design, Green-Design, Cleaner-Product concepts, etc. The way of reducing environmental impact from the natural resource consumptions relates to individual behaviour. Moreover, individual behaviour is a major factor lead to the increase or decrease consumptions.(Salleh, M.N.M., Kandarb,M.Z,Sakipc,S.R.MD.\& Johari, N., 2015) Therefore, the change will occur when we study about human behaviour to adapt the appropriate consumption behaviour. On the urban citizenship, we use energy and natural resources every day thru the product in daily life such as electric appliances or equipment that are a connector between the user and environmental use. On the other hand, the users do not perceive about the data consumption or impacts; they consume the resources carelessly and unaware. If the product can send data consumption to the consumer, it can enhance user's conception to change consumption behaviour appropriately.

\footnotetext{
${ }^{*}$ Corresponding author. Tel.: +66819083970

E-mail address: nonimailing@gmail.com
}

ISSN: 2398-42870 2017. The Authors. Published for AMER ABRA by e-International Publishing House, Ltd., UK. This is an open access article under the CC BYNC-ND license (http://creativecommons.org/licenses/by-nc-nd/4.0/). Peer-review under responsibility of AMER (Association of Malaysian Environment-Behaviour Researchers), ABRA (Association of Behavioural Researchers on Asians) and cE-Bs (Centre for Environment-Behaviour Studies), Faculty of Architecture, Planning \& Surveying, Universiti Teknologi MARA, Malaysia.

DOI: http://dx.doi.org/10.21834/e-bpj.v2i5.659 


\section{Literature Review}

\subsection{Sustainable behaviour and user attribute factors}

Many words to call a character action that conservation, saving, maintain the environment or minimize environmental resource, etc. (Latif, S. A., Omar, M. S., Bidi and Y. H. \& Awang, 2016), for example, pro-environmental behaviour, environmental-protective behaviour, environmental-preserving behaviour or environmentally friendly behaviour it similar meaning (Krajhanzl, 2010). A purpose of the learning on sustainable behaviour that for understanding the driver in environmental performance and the process then researcher divided into two section factor include internal factor and external factor (Kollmuss \& Agyeman, 2010). The internal factors, the main idea in the past started from the simple model base on two essential factors environmental knowledge and environmental attitude (Ajzen\& Fishbein, 1980),Kollmuss \& Agyeman (2010).

These factors have been fundamental elements in many kinds of research of environmental action and to involve an environmental awareness that is a necessary knowledge and root skill for solve the environmental problem. (Wichitra, S., Kidanun D., \& Warapon, K., 2012), (Sengupta, Das and Maji, 2010) Perceived consequences of behaviour (Kollmuss \& Agyeman, 2002) this factor is significant for knowledge in action and effect to all of the knowledge, attitude and awareness. In the external factors, A Hine's study (Hines et al., 1986) point out on an essential element that is the situation it means if people have an encouraging chance by facilitating some environmental information to user's perception to make the knowledge they will change to environmental performance. User attributes, the factors make a difference in the perception of environmental information in general situation context for example gender, age, education, income, technology usage, norm (Abraham, J \& Rufaedah, A., 2013) etc. base on environmental knowledge, environmental attitude and ecological awareness for discussion on distinction of the perception in environmental information such as environmental problems, individual consumption information, the solution information of the use problems

\subsection{The product design theory for user behaviour change}

The design concept has a target to user's behaviour change thru the product design. Design for Sustainable Behaviour (DfSB.) Began in the 1970s (Jelsma, 1997) and appeared prominently in the 2000s (Lilley,2007), (Bhamra et al.,2008),(Tang, 2010). The knowledge of DfSB. based on the User-Centred Design concept (UCD), Behavioral Psychology and Sustainability (Daae, 2014). Study on user's behaviour is a precious method in DfSB. It brings about to the real information from the real way to use the product. In the important strategies, design upon the axis of decision making between user and product named Design Intervention Strategies it has seven modes are as follow Eco-information, Eco-choice, Eco-feedback, Eco-spur, Eco-steer, Eco-technical Intervention and Clever design(Bhamra et al.,2008).

On the others hand, Persuasive Design (Fogg, 2009), this concept emphasis on behaviour target by three components include 1) Motivation or Motivator, 2) Simplicity or Ability and 3) Triggers. A success key in a concept is a motivator will be high ability enough and in the study of Fogg also created Behavior Grid (Fogg, 2009) it a guideline for learning about behaviour change characters. Numerous research in product design adapts this concept to useful product and also this study.

\subsection{Design enhancing environmental perception}

Design enhancing environmental perception is a design for incentive use's behaviour by informing some data such as consumption information, cue, signal and prompt throughout the product or the equipment in use-phase (consuming time) relates user's overt behaviour. This design concerns design for sustainable behaviour concept in the mode of eco-information and eco-feedback the characters of the design. There are 2 kinds 1) convey direct information display the real resource and use to user such as a Power Aware Cord design (Gustafsson \& Gyllenswärd, 2005) 2) communicate indirect information by technology called Eco-feedback Technology represent the data such as The ténéré power plug (Kim, W.K., Kim, Y.K. \& Nam, T.J., 2009) the design have a monitor present about use data by symbolic

\subsubsection{Informational contents}

The contents are crucial in the communication that each content will affect user's behaviour dissimilar in these research can separate as follow the table:

\begin{tabular}{|c|c|}
\hline informational Content & Descriptive \\
\hline Usage volume & $\begin{array}{l}\text { The volume of the use that seems represent of the user' s consumed action, for example, an } \\
\text { electric power volume from air-conditioning, washing machine that like report in the usage of } \\
\text { energy }\end{array}$ \\
\hline Statistic & $\begin{array}{l}\text { This content is a calculating information from a usage data it is high-level information for manage } \\
\text { in the consuming }\end{array}$ \\
\hline Comparison & $\begin{array}{l}\text { The set of usage content it recorded and comparing with others usage content set data such as: } \\
\text { comparing with historical data for the same period, } \\
\text { comparing with standard use and } \\
\text { comparing with others data in the similar activity in use }\end{array}$ \\
\hline Guidelines & $\begin{array}{l}\text { The data such a signal, cue, prompt for incentive or data approaches for reasonable practice such } \\
\text { as: }\end{array}$ \\
\hline & $\begin{array}{l}\text { The knowledge for the accurate energy consumption. } \\
\text { The method for the correct implementation }\end{array}$ \\
\hline Environmental Impacts & $\begin{array}{l}\text { An evaluate information from consuming data to impacts on environment such to emit of carbon } \\
\text { dioxide volume in that consumption }\end{array}$ \\
\hline
\end{tabular}


Table 2. Informational Content

\begin{tabular}{cl}
\hline informational Content & Descriptive \\
\hline Cost \\
Goal setting & $\begin{array}{l}\text { Economic data from the energy and natural resource usage. } \\
\text { set of data created by user for approach control consumption such The target of reducing energy } \\
\text { consumption by } 5 \% \text { this content will display the data when user requirement }\end{array}$ \\
\hline
\end{tabular}

\subsubsection{Design elements}

In a communication dependent on something that conveys a meaning to an audience it called the code. That is very crucial because when the audience received the code which will be interpreting if the code unable to get through the meaning or disconnect the audience's apperception that communication will be unsuccessful. The code in this study that is designed element for display design from element design in communicational meaning we sorted the design into two category

\subsubsection{Constant meaning communication design}

Design elements that constant a meaning and socially accepted in the implication include:

$$
\begin{aligned}
& \text {-Letter } \\
& \text {-Number } \\
& \text {-Graph }
\end{aligned}
$$

Advantages of this design element it has been using for a long time, general understanding, to give data implication deeply and in the cons, the user must be reading comprehension, understand in the graph, and it is unattractive

\subsubsection{Inconstant meaning communication design}

Design elements that changeable meaning which can improve or gives a new meaning include:

-Abstract Visualization

-Symbol

-Icon

Advantages of this design element it is very attractive, it can create in variety design. The lack of knowledge who can understand of data easier. In the cons, it cannot provide data implication deeply and must create an understanding to the user before

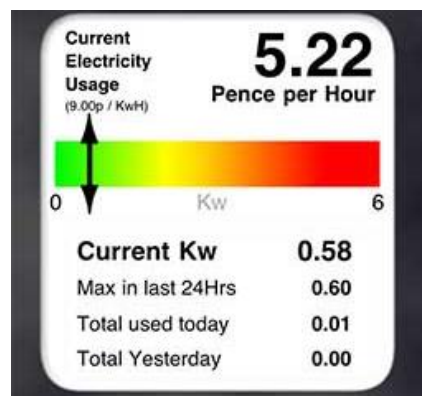

(a)

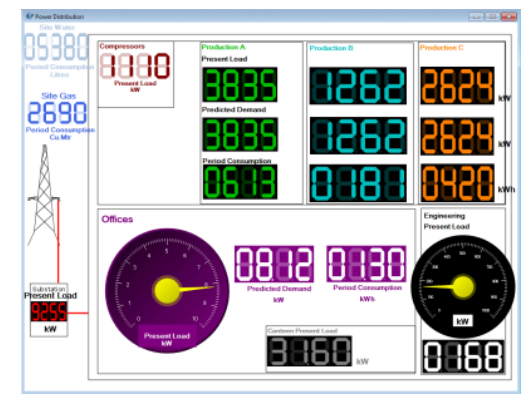

(b)

Fig. 1. (a) Letter display; (b) Number display.

(Source: Automated Home, 2016 (a); NewFound Energy Ltd, 2016 (b))

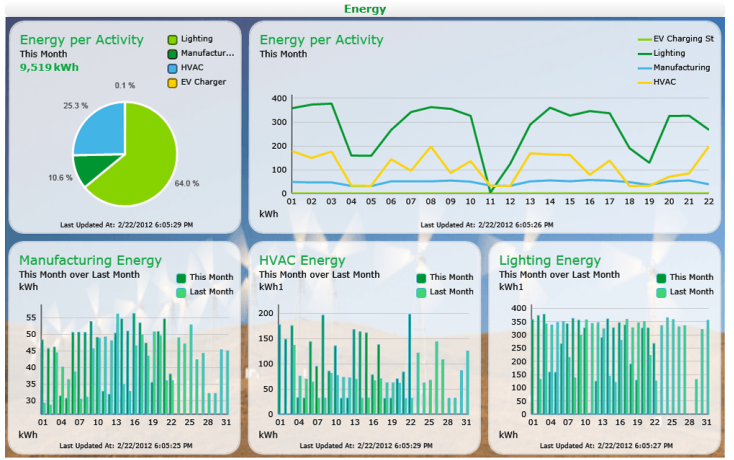

(c)

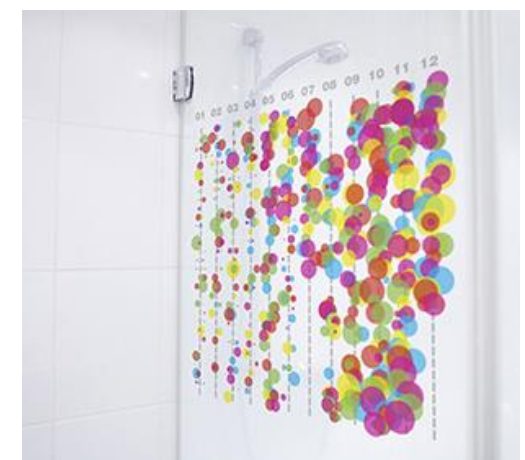

(d)

(Source: Hessman T., 2012 (c); Laschke \& Diefenbach and Hassenzahl, 2015 (d)) 

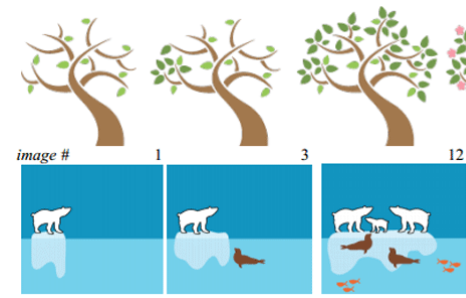

(f)

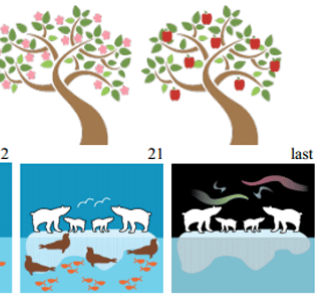

Fig. 3. (f) Symbol display; (g) Icon display. (Source: Hessman T., 2012 (f); Gladu, 2012 (g))

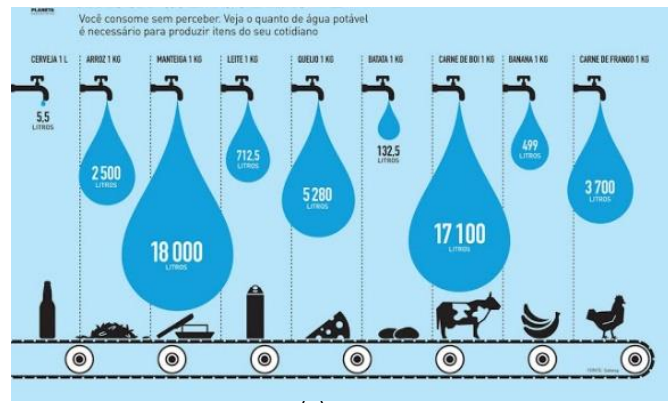

(g)

\subsubsection{Components and parts of product design}

1. Receptor is electronic parts which have a perceived function for connecting and collect the data to data collector or operational system

2. Data Collector is a database server that it is a tank of data and support system

3. Operational system /hardware/software, it is a computer program for running and manage all system

4. Monitor and Interface, this parts is an important which connect between user and system and a core of this learning

5. Network Controller is an electronic apparatus that communicate data to all device and equipment include: internal and external area

\subsection{Conceptual framework}

A conceptual framework divided the research into three parts which are the study of user attributes and behaviour and learning in design. In the last, analysis all factors

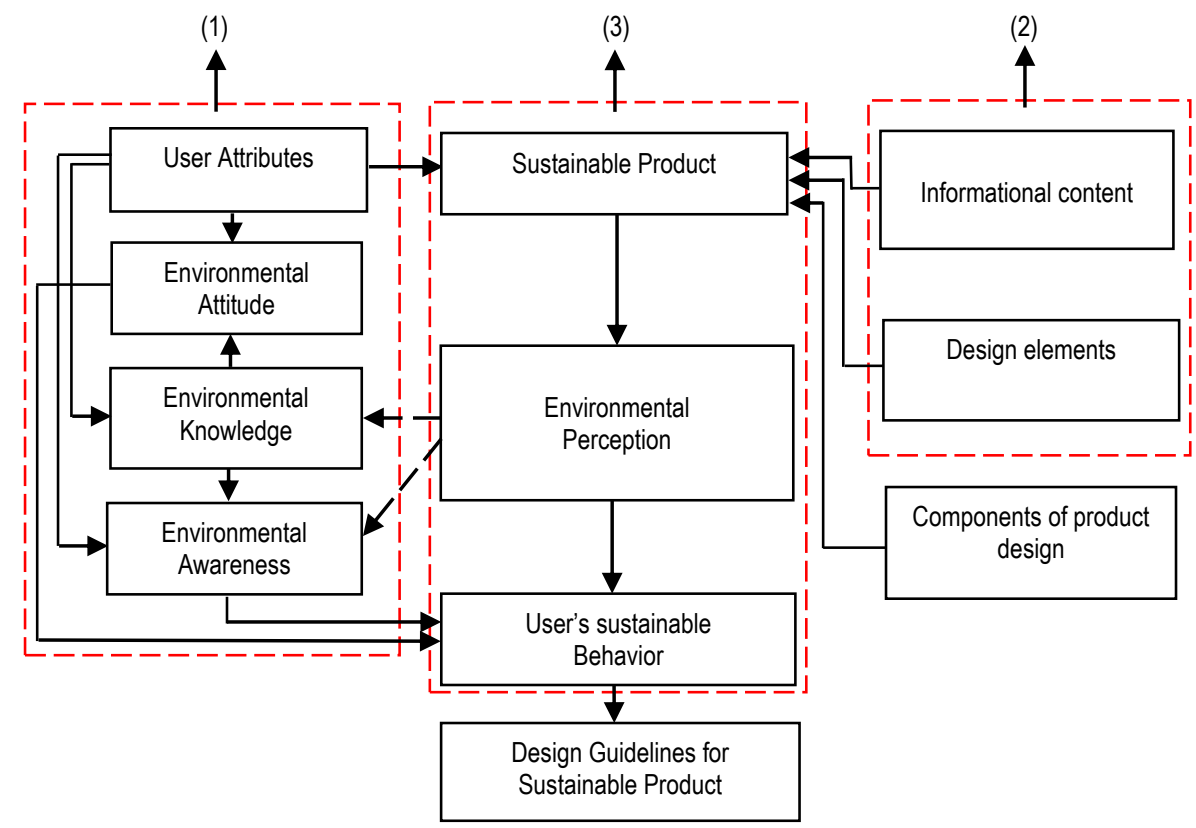

Fig. 4: Conceptual framework

\section{0 Methodology}

This research is an empirical research. A method used in mixed methods all qualitative research and quantitative research in collecting data. The study divided process in 3 phase include:

- The first step, user study we use a questionnaire a self-report and paper test for data collection and analyse the character of the user.

- $\quad$ Second step, design study by experiment informational content and the design elements with the user and evaluate the results and

- The last step, testing the prototype design and analyse the data. 
The present process has been studied in the first process. We use the questionnaire, self-report and paper test, the survey query about user's attributes include gender, age, education, occupation, income, house character, homeland and technological adaptation. The self-report on environmental attitude, environmental awareness and perceiving in environmental information and the paper test on environmental knowledge the result to respond in first aim object, to analyse user attribute factors that affect to perception distinction of environmental data and information

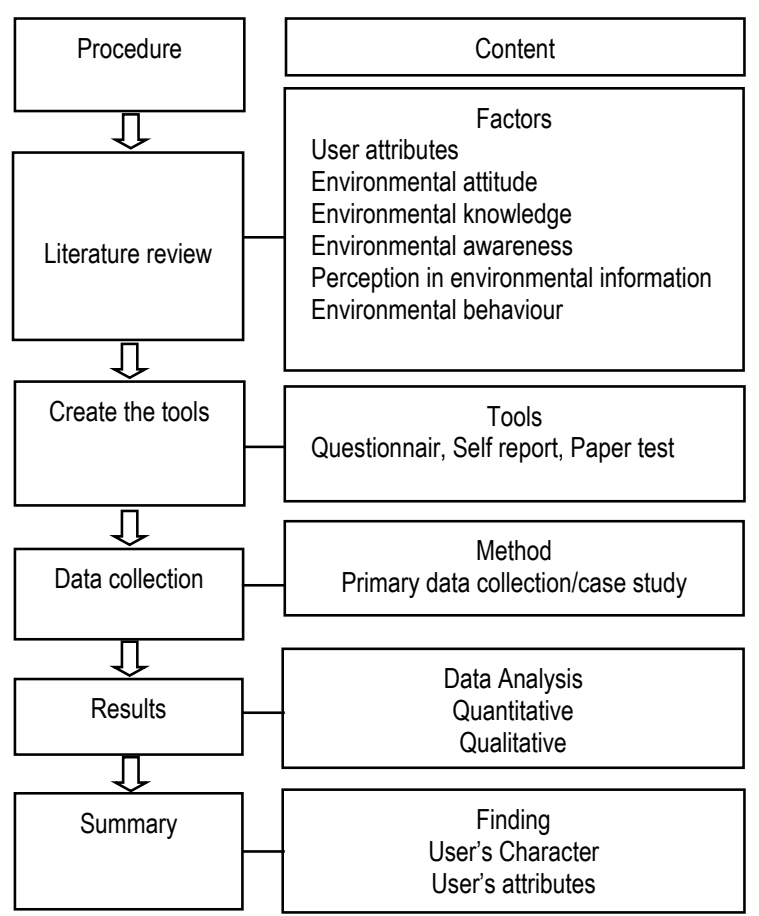

Fig. 5: Research procedure in phase 1

\subsection{Pilot questionnaire study}

The tryout of the tool for reliability as a case study at Rajamangala University of Technology Phra Nakhon, Bangkok, Thailand In the questionnaire have a topic about Environmental attitude, Environmental Awareness and Environmental behaviour.

Table 3. The user attribute factors and choices

\begin{tabular}{ll}
\hline \multicolumn{1}{c}{ Factors } & \multicolumn{1}{c}{ Choices } \\
\hline Gender & Male, Female \\
Age & Fill out \\
Education & Pre-primary school, primary school, Hi school, Bachelor, Graduate \\
Occupation & Student, Officer, Private Employees, Business Owner, Office employee, Private \\
& worker \\
& Farmer, State enterprise employees, General Worker, Home Maid, Other \\
Income & Fill out \\
House character & Single House, Condominium, Home Office \\
Homeland & Fill out \\
Technological usage & Fill out \\
- Time to use technological & \\
$\quad$ equipment per day & \\
(Computer, Smartphone, Tablet) & Ectivity use frequency
\end{tabular}

- self-report questionnaire

This tool use Likert scale in 1-5 level on user's opinion with strongly disagree to agree strongly

1 Strong disagree

2 disagree

3 Undecided

4 Agree

5 Strong agree 
Table 4. Factors and Questions in self-report questionnaire

\begin{tabular}{ll}
\hline \multicolumn{1}{c}{ Factors } & Questions \\
\hline Environmental attitude & 1.Should save electricity and water use, even though it did not reduce more \\
expenses decreasingly \\
2.Should use public transportation for getting close \\
3.Should buy energy-efficient appliances although cost more than general \\
appliances \\
4.Should buy and using products that can recycle \\
5.Should buy the goods and products that use local materials for to promote your \\
communities \\
6.Should always talk and campaign on environmental topic around your area \\
7.Should training youth and your child to consumption behaviour appropriately \\
8.Should record about electric and water use volume for consumptive \\
management \\
9.Should alway sorting the waste before disposal \\
10.All family members should perceive about house's consumption information \\
1. When you use the air-condition, it intend to use temperature in $25-26{ }^{\circ} \mathrm{C}$ \\
2. When you use a washing machine, it will wait for the volume loading of clothes \\
enough \\
3.When you buy clothes, it intend to buy durable more than \\
fashionable \\
4.When you have found a plumbing leak at another area, It will inform the \\
relevant departments. \\
5. When you are the first floor, however, must go to second or third floor of your \\
office, it intend to go to by walk \\
6. When you must go to unknown location, it always prepare information about the \\
route \\
7. when you know about an efficiency energy information, it always pass to your \\
friend \\
8. when your neighbourhood friend ask for cooperation for cleaning a public area, \\
it willing cooperation \\
9. when you buy the fruit, it will buy domestic fruit before \\
10.you always have an idea for consumption plan in your home \\
\end{tabular}

This tool use Likert scale in 1-5 level survey the behaviour in everyday life frequency

$$
\begin{array}{ll}
1 & \text { Seldom } \\
2 & \text { Occasionally } \\
3 & \text { Sometimes } \\
4 & \text { Frequently } \\
5 & \text { Always }
\end{array}
$$

Table 5. Factors and Questions in self-report questionnaire the behaviour in everyday life frequency

\begin{tabular}{ll}
\hline \multicolumn{1}{c}{ Factors } & \multicolumn{1}{c}{ Questions } \\
\hline Environmental behaviour & 1. Turn faucet off when washing dishes and bowls \\
2. Turn faucet off faucet when soap & 3. Turn lights off when you are not using room \\
4. Waiting for the volume loading of clothes enough when using washing machine \\
5 Iron numerous clothes per time \\
6.Buy energy-efficient appliances. \\
7.Buy the products it can recycle \\
8.Buy domestic produce \\
9.Buy domestic fruit and food \\
10.Buy non-chemical product
\end{tabular}

Table 6. Factors and Questions in self-report questionnaire the behaviour in everyday life frequency

\begin{tabular}{ll}
\hline \multicolumn{1}{c}{ Factors } & \multicolumn{1}{c}{ Questions } \\
\hline Environmental behaviour & 11.Buy the product that promoting economic locally \\
& 12.Share the environmental information on the social \\
& 13.Give a guidance on a journey to save energy to friends \\
14.Join an environmental volunteer event & 15.Persuade your neighbourhood friend for cleaning a public area \\
& 16.Teach youth and your child to consumption behaviour appropriately \\
17.Sort the waste before disposal & 18.Dispose of the hazardous waste properly \\
19.Record and check about electrical consumption in house & 20.Plan a route to save power when you drive to unknown location \\
\end{tabular}




\subsection{Results}

The tryout conducts with bachelor's degree student at Rajamangala University of Technology Phra Nakhon, Bangkok. The samplings are $n=57$, male 27 female 30, age between $19-23$ years old, $68.4 \%$ rest in single house and $75.4 \%$ live in Bangkok

- Environmental attitude Questions

Reliability Cofficients $n=10$ Alpha $=.7001$

- Environmental awaress Questions

Reliability Cofficients $n=10$ Alpha $=.7971$

- Environmental behaviour Questions

Reliability Coefficients $n=20$ Alpha $=.8662$

The first finding result, we tested correlation statistic (Pearson Correlation) to all factors that discover the correlation between Environmental attitude and Environmental awareness significantly at $.758^{* *}(0.01$ level)

\section{Conclusion}

The research has been developing in the tool. The result of the tryout will improve some question before data collection in the first step. In the question should separate on sub-topic such as consuming action, purchase decision (Juniora, S.S.B., Silvab,D.D., Gabrielb,M.L.S \& Braga, W.R.O., 2015) management and social. When complete data collection that leads to the analysis of data to finding follow the object to analyse user attribute factors that affect to perception distinction of environmental information and to conduct next step.

People on the world consume energy and natural resources every day. Environmental information has been significant for connecting between the user and environmental use. This study endeavour communication the information for supporting user environmental perception. If everybody can change the wasting behaviour that is a sustainable way for protection and conservation the earth for next generation.

\section{Acknowledgement}

The authors would like to acknowledge Rajamangala University of Technology Phra Nakhon for funding, and I am heartily thankful to my advisor Asst. Prof. Dr. Yanin Rugwongwan and co-advisor Dr.Wichitra Singhirunnusorn

\section{Reference}

Abraham, J \& Rufaedah, A. (2013) Pro-Environment Being and Ecological Attachments. Journal of ASIAN Behavioural Studies, Bina Nusantara University, Indonesia, pp.55-62.

Ajzen,I \& M Fishbein.(1980) Understanding Attitudes and Predicting Social Behaviour. Englewood Cliffs, NJ: Prentice-Hall Inc.

Automated Home.(2016). Eco Meter. Retrieved Dec 10, 2016, from http://www.automatedhome.co.uk/reviews/lightwaverf-home-automation-system-in-depthreview.html

Bhamra, T.A., Lilley, D. and Tang, T. (2008b) Sustainable use: changing consumer behaviour through product design. Changing the change: design visions, proposals and tools, 10-12 July 2008, Turin, Italy.

Daae, J. L. (2014). Informing Design for Sustainable Behaviour. Trondheim, Norway: Norwegian University of Science and Technology.energy.co.uk/atlasevo-energymanagement-systems/

Fogg, B. (2009). A Behavior Model for Persuasive Design. CA, USA: Stanford University.

Fogg, BJ, 2009b, 'A Behavior Model for Persuasive Design', in the Proceedings of the 4th International Conference on Persuasive Technology, Claremont, CA, USA April 26-29

Gladu C. (2012). UbiGreen: Eco-feedback on the go. Retrieved Dec 11, 2016, from http://ecofeedback.ca/?p=165

Gustafsson, A \& Gyllenswärd, M. (2005) The Power-Aware Cord: Energy Awareness through Ambient Information Display. CHI 2005 extended abstracts on human factors in computing systems. pp. 1423-1426.

Hessman T. (2012). Beyond Smart Energy. Retrieved Dec 10, 2016, from http://www.industryweek.com/technology/beyond-smart-energy

Hines, J. M., Hungerford, H.R. \& Tomera, A.N. (1986-87). Analysis and synthesis of research on responsible pro-environmental behaviour: a meta-analysis, Journal of Environmental Education, 18(2), pp. 1-8.

Juniora, S.S.B., Silvab,D.D., Gabrielb,M.L.S \& Braga, W.R.O. (2015). The Effects of Environmental Concern on Purchase of Green Products in Retail. Procedia - Social and Behavioral Sciences, College of Administration Brazil, pp 99-108.

Kim, W.K., Kim, Y.K. \& Nam, T.J. (2009). The Ténéré: Design for Supporting Energy Conservation Behaviors. CHI 2009. Boston, MA, USA 
Kollmuss, A., \& Agyeman, J. (2002). Mind the Gap: Why do people act environmentally and what are the barriers to pro-environmental behavior. Environmental Education Research, 239-260.

Krajhanzl J. (2010). Environmental and Proenvironmental Behavior in School and Health 21. Health Education: International Experiences, editor Evzen Remulka, Bruno Press, pp. 251-274.

Latif, S. A., Omar, M. S., Bidi, Y. H. \& Awang, Z. (2016) Creating Pro-Environmental Residents: The role of environmental knowledge. Asian Journal of Behavioural Studies, Universiti Teknologi MARA Malaysia, pp.13-22.

Lilley, D. (2007). Designing for Behavioural Change: Reducing the Social Impacts of Product Use through Design. PhD Thesis, Loughborough, UK: Department of Design and Technology, Loughborough University.

NewFound Energy Ltd, (2016). Monitor Live Energy Usage. Retrieved Dec 10, 2016, from http://www.newfound-

Salleh, M.N.M., Kandarb,M.Z,.Sakipc,S.R.MD.\& Johari, N. (2015). Users' Perception of Energy Efficiency in School Design. Procedia - $\quad$ Social and Behavioral Sciences, University Sains Malaysia, pp 155-164.

Sengupta, M., Das, J. and Maji. (2010). Environmental Awareness and Environmental Related Behaviour of Twelfth Grade Students in Kolkata: Effects of Stream and Gender, Anwesa, Vol.5, pp 1-8.

Tang, T. (2010). Towards sustainable use: designing behaviour intervention to reduce household environmental impact. PhD Thesis, Loughborough, Uk: Department of Design and Technology, Loughborough University.

United Nations. (1987) Report of the World Commission on Environment and Development Our Common Future NY, USA United Nations.

Vasconcelos C. (2013). Water in Norway. Retrieved Dec 11, 2016, from http://vannplanet.blogspot.com/2013/05/a-agua-que-voce-nao-ve.html

Wichitra, S., Kidanun D., \& Warapon, K. (2012). Household Recycling Behaviours and Attitudes toward Waste Bank Project: Mahasarakham Municipality. Journal of ASIAN Behavioural Studies, 2(6), 35-47.

Yusof, Z.B.BT. \& Jamaludin, M. (2015). Green Practices of Small Island Chalet Operators in East Peninsular Malaysia. Procedia - Social and Behavioral Sciences, International Islamic University Malaysia, pp.340-350. 